\author{
УДК 323:316.4 \\ https://doi.org/10.34142/24130060.2019.18.2.04
}

\title{
ПРОБЛЕМИ ТРАНСФОРМАЦІЇ ПОЛІТИЧНОЇ СУБ’СКТНОСТІ В ПОСТІНДУСТРІАЛЬНОМУ СУСПІЛЬСТВІ
}

\author{
О.В. Воронянський \\ Харківський національний технічний університет сільського господарства \\ імені Петра Василенка
}

Перехід економічної системи на постіндустріальний рівень кардинально змінив соиіальну структуру суспільства. Організований робітничий клас і його масові партії, чия ідеологія базувалася на усвідомленні системної класової спільності в прочесі виробництва, поступилися місцем не пов'язаним із циим процесом дрібним спільнотам, які об'єднуються на основі культурних кодів спожсивання. Відповідно, перехід від класової суб'єктності індустріального суспільства до фрагментованої декласованої суб'єктності постіндустріалізму для більшості населення означає відмову від боротьби за реальні інтереси на користь сформованих політичною елітою симулякрів изих інтересів. Дії таких суб'єктів у межах нав'язаних їм кодів культури споживання не призводить до зміни реального політичного порядку, не дозволяють, а лише тимчасово компенсують зростаючі структурні політичні конфлікти.

У період постіндустріального суспільства вичерпання можливостей ринкового розподілу ресурсів створює тенденцію переходу від реальної економічної діяльності до ренто-орієнтованої поведінки. Однак така форма задоволення соиіальних запитів створює загрозливу тенденцію до самознищення самої інфраструктури сучасного суспільства і подальшої фрагментацією простору політичної суб'єктності.

Повернення реальної політичної суб'єктності більшості може бути пов'язано $з$ трансформацією розрізнених груп у новий політичний клас. Ці иілі мають на увазі легітимізацію нового політичного порядку, в якому ієрархія доступів до ресурсів суспільства перестає бути ключовим фактором сочіальної стратифікачії.

Ключові слова: політична суб’єктність, постіндустріалізм, ренто-орієнтована поведінка, розподіл ресурсів.

\section{ПРОБЛЕМЫ ТРАНСФОРМАЦИИ ПОЛИТИЧЕСКОЙ СУБЪЕКТНОСТИ В ПОСТИНДУСТРИАЛЬНОМ ОБЩЕСТВЕ}

\section{А.В. Воронянский}

Переход экономической системы на постиндустриальный уровень кардинально изменил сочиильную структуру общества. Организованный рабочий класс и его массовые партии, чья идеология базировалась на осознании системной классовой общности в процессе производства, уступили место не связанным с этим процессом мелким общностям, объединяютимся на основе культурных кодов потребления. Соответственно, переход от классовой субъектности индустриального общества к фрагментированной декласированной субъектности постиндустриализма для большинства населения означает отказ от борьбы за реальные интересы в пользу сформированных политической элитой симулякров этих интересов. Действия таких

(c) О.В. Воронянський, 2019 
субъектов в пределах навязанных им кодов культуры потребления не приводит к изменению реального политического порядка. не разрешают, а лишь временно компенсируют растущие структурные политические конфликты. $B$ период постиндустриального общества исчерпание возможностей рыночного распределения ресурсов создает тенденщию перехода от реальной экономической деятельности к ренто ориентированному поведению. Однако такая форма удовлетворения сочиальных запросов создает угрожающую тенденцию $\kappa$ самоуничтожению самой инфраструктуры современного общества и дальнейшей фрагментаџией пространства политической субъектности.

Возвращение реальной политической субъектности большинства может быть связано с трансформаџией разрозненных групп в новый политический класс. Эти иели подразумевают легитимизацию нового политического порядка, в котором иерархия доступов к ресурсам общества перестает быть ключевым фактором сочииальнй стратификации.

Ключевые слова: политическая субъектность, постиндустриализм, рентоориентированное поведение, распределение ресурсов.

\section{PROBLEMS OF POLITICAL PERSONALITY TRANSFORMATION IN THE POST-INDUSTRIAL SOCIETY}

\section{O. Voronianskyi}

The transition of the economic system to the post-industrial level has radically changed the social structure of society. The organized working class and its mass parties, whose ideology was based on the recognition of a systematic class community in the production process, gave way to small communities unrelated to this process, uniting on the basis of cultural consumption codes. Accordingly, the transition from the class subjectivity of industrial society to the fragmented declared subjectivity of post-industrialism for the majority of the population means refusing to fight for real interests in favor of simulated by the political elite of these interests. The actions of such entities within the limits of the codes of consumption culture imposed on them do not lead to a change in the real political order. They do not allow, but only temporarily compensate for the growing structural political conflicts. In the period of post-industrial society, the exhaustion of the possibilities of market distribution of resources creates a tendency to move from real economic activity to rent seeking. However, this form of satisfying social needs creates a threatening tendency toward self-destruction of the very infrastructure of modern society and the further fragmentation of the space of political subjectivity.

The return of the real political subjectivity of the majority may be associated with the transformation of disparate groups into a new political class. These goals imply the legitimization of a new political order in which the hierarchy of access to society's resources is no longer a key factor in social stratification.

Key words: political subjectivity, post-industrialism, rent seeking, resource distribution.

Постановка проблеми. Особливістю сучасного етапу політичного процесу стало очевидне протиріччя між суттєвим збільшенням кількості та масовості протестних політичних акцій у всьому світі з одного боку, та мізерністю їх результативності (покращенння життєвого положення та підвищення соціального статусу) для основної маси учасників цих акцій - 3 другого. Можна припустити, що дана тенденція складається внаслідок 
неспроможності основної маси населення до осмислення раціональних цілей і методів боротьби за свої політичні права. Враховуючи, що в період існування індустріального суспільства, який передував сучасному постіндустріалізму, масові протестні рухи були не лише організованими та цілеспрямованими, але й приводили до системного покращення статусу основної маси населення (головними результатами тут можна назвати перехід до політичної рівноправності та соціальних гарантій з боку держави), вважається необхідним поставити питання про причини та наслідки змін характеристик політичної суб’ єктності мас.

Аналіз актуальних досліджень. Наукові дослідження проблеми трансформації політичної суб’єктності в постіндустріальному суспільстві представлені в обмеженому обсязі. Деякі аспекти цього процесу розглянуто в роботах зарубіжних та вітчизняних дослідників Г. Девіса, I. Денисенко, Ф. Джеймсона, Ю. Зайончковського, Д. Іванова, Р. Маквея, В. Мартьянова, О. Михайлюка, Л. Фішмана та інших.

Метою статті є розгляд та теоретичний аналіз основних причин та наслідків трансформації політичної суб’єктності в постіндустріальному суспільстві.

Виклад основного матеріалу. Економічний спад та падіння норми прибутку у розвинених економіках призвели до перегляду існуючого соціального компромісу, переходу до неоліберальної за ідеологічним змістом політичної системи (сутністю якої $є$ закріплення системного скорочення соціальних витрат) та постіндустріальної економіки. Автоматизація виробництва, що ознаменувала перехід суспільства 3 індустріального на постіндустріальний рівень, змінила соціальну структуру суспільства, оскільки багаточисленний i організований клас промислових робітників перестав існувати, поступившись місцем дрібним підприємцям та найманим працівникам сфери послуг. Однак динаміка світової економічної системи продовжує демонструвати тенденції, які засвідчують реальність ризику вичерпання можливостей існуючих сьогодні інституційних підвалин 
економічного зростання вже в середньостроковому майбутньому (Фишман, 2016, с. 123-124). Причому, якщо в період індустріального суспільства ринок міг безкінечно розширюватися за рахунок поглинення територій і населення, не включених до того в процес капіталістичного обміну, то в постіндустріальний період така можливість фактично вичерпана. Світовий ринок набуває статусу закритої системи 3 обмеженими ресурсами. А виключення маси працівників із процесу виробництва, у свою чергу, веде до скорочення ємності споживацького ринку і як наслідок - до зменшення обсягів податкових надходжень, необхідних для формування фінансової бази державних програм.

Продуктом розпаду робітничого класу, який існував у епоху індустріального капіталізму, став цілий набір декласованих соціальних груп і меншин, об’єднаних нисхідною тенденцією соціальної мобільності. Фактично всі вони виявилися витисненими на периферію економічної системи і вимушені задовольнятися, в основному, різними видами соціальної допомоги для підтримки споживацької спроможності - від нульових кредитів до прямих державних дотацій. При цьому спільність їх статусу в якості дискримінованих постіндустріальною соціально-економічною системою спільнот поєднується з гострою конкуренцією зазначених груп за доступ до такої допомоги (Jameson, 1992). Політичній консолідації цих груп на класовоідеологічних засадах навколо спільних довгострокових інтересів перешкоджає побудоване на основі постмодерністської споживчої культури мислення, де смислові акценти ставляться на різноманітних відмінностях, деконструкції та конфліктах (Вершина та Михайлюк, 2002), коли політичні логіки локальності і партикулярності не дозволяють організувати ефективну колективну політичну взаємодію. Тому дрібні соціальні групи об’єднуються не на основі загальних інтересів, що обумовлені їх спільним положенням на ринку праці (що було характерним для індустріального суспільства), а ефемерними гендерними, фанатськими та субкультурними ідентичностями, а також спільними страхами, виробляючи при цьому досить стійкі культурні 
коди (Денисенко, 2015). Відповідно зійшли з політичної арени і системні носії класової ідеології - масові партії, оскільки сегментація суспільства разом із підвищенням рівня споживання в період останньої третини ХХ ст. значно знизила попит на політичне представництво інтересів більшості.

Наслідком такої трансформації соціальної структури стало домінування в свідомості основної маси населення нездатності до осмислення реальних власних інтересів, які виявилися повністю заміщеними їх культурними симулякрами (Денисенко, 2010). Як осмислення інтересів і шляхів їх досягнення, так і впровадження в суспільну свідомість віртуальних симулякрів цих інтересів є достатньо дорогим процесом і потребує підтримки 3 боку основних соціальних інститутів. Реалізувати його здатна лише суспільна група, яка має високий рівень політичної суб'єктності, тобто не лише усвідомлює свої специфічні політичні інтереси, але й має достатній рівень організованості та концентрації ресурсів влади для їх забезпечення. В індустріальному класовому суспільстві, так само як і в патріархальному, що передувало йому, ця діяльність здійснювалася через функціонування стійких соціальних об’єднань - громад, станів, корпорацій, класових партій, які завдяки об’єднанню власників дрібних ресурсів могли сконцентрувати достатній для здійснення політичної діяльності мегаресурс.

В умовах сегментованості постіндустріального суспільства таким ресурсом володіють лише потужні бізнес-групи. Їх основним інтересом є оволодіння інститутом держави як основним механізмом контролю над розподілом ресурсів. Таким чином, процес формування політичної ідеології носить конкурентний характер боротьби за вплив на прийняття державних рішень і в кінцевому підсумку - державну владу. Від реалізації державної влади чи впливу на неї бізнес-групи (які набувають статусу політичної еліти та олігархату) отримують ренту як у вигляді пільгового доступу до ресурсів, так і через отримання плати за їх розподіл на користь інших груп. Бізнесгрупи, просуваючи свої специфічні інтереси через політичну систему, намагаються надати їм характеру загальносуспільних для того, щоб у 
боротьбі 3 конкуруючими угрупуваннями заручитися підтримкою «більшості». Тому фактично в постіндустріальному суспільстві 3 його великим розривом рівнів прибутків та соціальною фрагментацією впроваджені цими групами в політичну свідомість симулякри соціальних інтересів стають системною ланкою механізму політичного панування економічно домінуючої соціальної групи.

У результаті керовані потужними бізнес-групами дії «більшості» в політичному просторі (від голосування на виборах за представників олігархату до участі в організованих зарубіжними конкурентами вітчизняних олігархів «кольорових революціях») у реальності не ведуть до принципової зміни існуючого політичного порядку, в найбільш крайньому випадку зводячись до технічних змін інституційного дизайну політичної системи.

Також втраті основною масою населення політичної суб’єктності сприяє значне ускладнення політичної діяльності як такої (Денисенко, 2013 ), що потребує значно більшого рівня знань та здатності приймати раціональні (тобто засновані на власних реальних інтересах та вірній оцінці співвідношення затратності визначених шляхів їх досягнення до вигоди від отриманих результатів) рішення в умовах системної дезінформації та неповної інформованості (Денисенко, 2010). Відтак для політичних еліт стало можливим винесення суттєвого масиву владних рішень щодо перерозподілу (разом із процесом їх підготовки та наступної реалізації) за рамки комплексу інформації, доступної для більшості. Це в перспективі зумовлює зведення нанівець i процесу політичної участі для останньої. Таким чином, концентрація економічних ресурсів, конвертована в ефективне застосування масиву ресурсів інформаційного та духовного характеру, дозволяє заблокувати здатність основної частини постіндустріального суспільства (яка на інституційному рівні формально продовжує вважатися носієм державного суверенітету) до набуття реальної політичної суб’єктності.

Каналізація соціального протесту відбувається в напрямку боротьби за певні привілеї в регульованому владною елітою порядку доступу до 
суспільних ресурсів, які дозволили б соціальним «низам» імітувати споживання «верхів», однак не надавали б можливості отримати самостійний доступ до центрів розподілу, який дозволяє підтримувати елітарний рівень споживання і статус еліти як розпорядника ресурсів. Такі привілеї фактично набувають характеру ренти від здатності реалізувати політичний вплив на центри прийняття владних рішень. В індустріальному суспільстві, так само як і в традиційному, боротьба за таку ренту була справою політичної еліти i квазіелітних груп, які обслуговували останню та захищали їі статус. Основна ж маса суспільства отримувала засоби до існування через систему первинного, економічного розподілу, а не через вторинний політичний.

Однак проблемою сучасного суспільства $\epsilon$ те, що рентоорієнтована поведінка, пов’язана 3 політичним доступом до ресурсів, в умовах структурної кризи споживацького ринку і падіння прибутків 3 капіталу, стає найбільш простою і найменш затратною стратегією практично для всіх без виключення суб’єктів політичних відносин.

Сьогодні пільговий доступ до ресурсів все менше пов’язаний зі здатністю до праці, ринковими інвестиціями або затребуваністю на ринку, i все частіше - 3 доступом до влади і місцем соціальних груп в ієрархіях привілеїв незалежно від класифікації конкретних суспільств як демократичних / недемократичних, ринкових / неринкових. Зазначена тенденція описується в нормативному дискурсі ринково-демократичної модернізації як архаїзація суспільства, повернення до рентно-станового політичного порядку, який прийнято описувати через концепції неопатримоніалізму та неофеодалізму (Зайончковський та Осіпов, 2019). Проте рентоорієнтована поведінка, що описується нормативними неоліберальними теоріями як поведінка паразитична, характерна для нерозвинених i деформованих суспільств, все частіше набуває ознак домінуючої політичної стратегії бізнес-груп, корпорацій і громадян навіть у «взірцевих» ринкових і демократичних суспільствах, які становлять ядро 
світової економіки, де умовою рентного доступу до гідного соціального пакету стає сам факт наявності / відсутності громадянства (Фишман, 2017).

У перспективі дана тенденція може привести до заміни ринкового капіталізму глобальною рентно-розподільчою моделлю владноадміністративного порядку, де політичні чинники стратифікації суспільства знову виходять на перший план, витісняючи домінування ринкового обміну. Все більше число соціальних груп перетворюється на заручників рентного доступу, втрачаючи інші джерела існування, в той час як ринок скасовує сам себе, відсуваючи на периферію економічний обмін ресурсами і переростаючи в рентний капіталізм, де основний розподіл ресурсів і соціальних статусів відбувається через механізм держави.

У такій конфігурації економічний розподіл неминуче стає похідним від політичного порядку, обумовленого динамікою інституційної конфігурації суб'єктів політики, які розподіляють ресурси на позаекономічних підставах. Звідси постає перспектива все більшого перетікання капіталу з реальної економіки в політичну сферу, оскільки інвестиції в статус учасника прийняття владних рішень щодо розподілу суспільних ресурсів стають на порядок більш прибутковими, ніж інвестиції в будь-які економічні проекти (Jameson, 1992). Інвестування ж у розвиток та відтворення соціальноекономічної інфраструктури суспільства, які завжди є більш затратними i ризикованими, ніж капіталовкладення в торгово-фінансові операції, неминуче відсторонюються на периферію економічної діяльності. Скорочення обсягу затрат на виробництво реальних матеріальних благ має наслідком і скорочення обсягів ресурсів, доступних для владного розподілу. Це, у свою чергу, неминуче загострює конкуренцію за доступ до політичної ренти i викликає постійне збільшення частки ресурсів, які замість відтворення інфраструктури та споживання відчужуються на ведення конкурентної боротьби. Саме така перспектива ще в останній третині XIX ст. описувалася як «загнивання» капіталістичної системи. 
Зазначена перспектива різко знижує загальну ефективність рентоорієнтованих стратегій, що апелюють до держави, та радикалізує всі наявні, в тому числі заморожені політичні протиріччя, вирішувати які шляхом рентних роздач буде все складніше. Окрема проблема полягає в тому, що загальна розповсюдженість рентоорієнтованої поведінки розмиває консолідуючі політичні інститути нації-держави і нівелює засоби вирішення внутрішніх конфліктів, пов’язані з територіальним суверенітетом, виборними процедурами і механізмами вироблення суспільного компромісу за допомогою моделі соціальної держави (Зайончковський та Осіпов, 2019; Мартьянов, 2017).

Відповідно силові лінії основних політичних конфліктів і розломів будуть неминуче пов’язані з правом системного контролю на різних рівнях політичної і економічної інфраструктур окремих соціальних груп, політичних угруповань і держави як суб’єктів розподілу ресурсних потоків; диференційованою зміною засад доступу громадян та соціальних груп до суспільних ресурсів; правами на політичну ренту і виключенням в першу чергу не-громадян із процесу рентного доступу (Мартьянов, 2017).

Даний сценарій розвитку існуючої тенденції трансформації політичної суб’єктності, пов’язаний із постійним загостренням боротьби за перерозподіл все більш обмеженого обсягу ресурсів веде до розвалу існуючої соціальної і економічної інфраструктур суспільства.

Виходом може стати глобальний перехід до нової системи економічних відносин, яка не $є$ функціональним продовженням капіталістичної конкуренції за прибуток, але має на меті ефективний, гармонійний розвиток соціально-економічної інфраструктури суспільства без надлишкових затрат на статусне споживання. Лише такий перехід дозволяє відмовитися від подальшої фрагментації політичної суб’єктності, що неминуче супроводжує загрозу загострення політичної конкуренції за контроль над обмеженими ресурсами в закритій системі. Консолідація ж політичної суб’єктності 
можлива ж лише на альтернативних споживацьким ціннісних підставах, які передбачають вихід за межі отримання індивідуальних і групових вигод.

Висновки та перспективи подальших досліджень. У даний час можна відзначити кілька глобальних фонових зрушень, які ведуть до перетворення суб’єктів постіндустріального суспільства. По-перше, це радикалізація нерівності як всередині суспільств, так і між ними, пов’язана 3 відмовою від моделі соціальної держави. По-друге, повільна, але неухильна втрата ринком домінуючих позицій в області соціальної стратифікації, яка все сильніше компенсується поверненням регулятивної ролі держави. Потретє, внаслідок неухильного виключення людини 3 автоматизованих i роботизованих виробничих процесів спостерігається розширення прошарку зайвих людей, який вбачає у виборюванні ренти від впливу на центри прийняття владних рішень єдину можливість для забезпечення свого існування.

Загальна конкуренція різноманітних соціальних груп і політичних угруповань за право на присвоєння ренти, що перетворюється на сутність політичної взаємодії постіндустріального суспільства (в ідеологічному плані виражаючись як популізм), не зачіпає сутності самої системи пізнього капіталізму: олігополії в умовах вичерпання ємності споживацького ринку.

У результаті політичні зміни, яких домагаються суб’єкти політичної діï, залишаються досить поверхневими. Ці зміни не дозволяють реконструювати соціальні інститути постіндустріального суспільства занепаду, а лише посилюють і маскують його протиріччя. Нерозв’язані конфлікти лише компенсуються рентними роздачами без усунення їх структурних причин.

Повернення політичної суб’єктності прямо пов’язане з перетворенням розрізнених груп в новий політичної клас для себе, коли погіршення рівня життя i закриття соціальних ліфтів спонукають його до колективних політичних дій, що розхитують панування споживчої культури, на якому заснована легітимація існуючого політичного порядку. Ці дії мають бути 
орієнтовані не на популістський дискурс, а на заміну системи базових координат політичного проекту постіндустріального суспільства.

\section{ЛIТЕРАТУРА}

1. Вершина, В. А. та Михайлюк, А. В., 2002.0 карнавальных истоках современной цивилизации. Докса: зб. наук. пращь з філософії та філологіï, 2, с. 124-132.

2. Денисенко, І. Д., 2010. Проблемне поле методології політичних досліджень. Вісник Національної юридччної академії України імені Ярослава Мудрого. Філософія, філософія права, політологія, соціологія, 5, с. 116-124.

3. Денисенко, І. Д., 2015. Теорія соціального простору: евристичний потенціал щодо соціально-політичних досліджень. Сучасне суспільство: політичні науки, соиіологічні науки, культурологічні науки, 2(10), с. 27-37.

4. Денисенко, I. Д., 2013. Сучасна теорія конфлікту: проблеми експлікації, демаркації, класифікації. Українській соичум, 3(46), с. 16-26.

5. Зайончковський, Ю. В. та Осіпов, О. М., 2019. Неокорпоративізм в умовах глобалізації: досвід Західної Європи. Сучасне суспільство: політичні науки, соціологічні науки, культурологічні науки, 2(16), с.98-107.

6. Мартьянов, В. С., 2017. Политические пределы homo economicus. Общественные науки и современность, 2, с. 104-118.

7. Фишман, Л. Г., 2017. Популизм - это надолго. Полис. Политические исследования, 3, c. $55-70$.

8. Фишман, Л.Г., 2016. Закат «общества труда»: современная идеологическая констелляция. Полития, 3, с.116-129.

9. Jameson, F., 1992. Postmodernism or The Cultural Logic of Late Capitalism. Durham: Duke University Press.

\section{Інформація про автора}

Воронянський Олександр Володимирович - кандидат історичних наук, професор, професор кафедри ЮНЕСКО «Філософія людського спілкування» та соціальногуманітарних дисциплін Харківського національного технічного університету сільського господарства імені Петра Василенка; e-mail: voronyansky@gmail.com; ORCID: http://orcid.org/0000-0003-4926-8887.

Стаття надійшла до редакції: 13.02.2019 р. $\quad$ Прийнята до друку: 22.02.2019 p. 